\title{
2019 Fund for Latino Scholarship Recipients
}

T he Latino Scholarship Fund's primary goal is to encourage and support the recruitment, retention, and promotion of Latina/o political scientists (especially students and tenure track junior faculty); the secondary goal is to support research on Latino politics in the United States (especially students and tenure track junior faculty). Grants for the 2019 cycle were awarded to those individuals, institutions, and projects whose purposes most clearly match the goals of the fund, and whose proposals most persuasively demonstrate capacity for successful completion. Applications for the fund close annually each June. Learn more about this year's fund recipients:

Rebeca J. Agosto Rosa is a political science graduate student at the University of Illinois, Urbana-Champaign. She studies American politics with a focus on political psychology and identity. Her dissertation project examines under what conditions and why foreign language cues affect political attitudes in non-political contexts. Support from the Fund for Latino Scholarship will assist in her travel

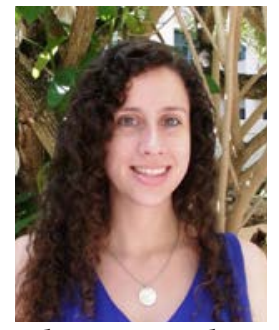
to the 2019 APSA Annual Meeting, where she will present her work on the political consequences of Spanish language cues in non-political media. She will also attend the Political Psychology pre-conference and the Latino Politics Workshop. She is a Schroeder fellow at the Cline Center for Advanced Social Research, a Harry S. Truman scholar, and a recipient of the Rita and Leonard Ogren Prize. She holds a master's degree in political science from UIUC and a bachelor's degree in political science and journalism from the University of Puerto Rico, Río Piedras.

Alejandro Beltran Aguirre is a $\mathrm{PhD}$ candidate at the School of Government and Public Policy of the University of Arizona. He received his BA from the Universidad Autónoma de Sinaloa and has a book on local governance in Spanish published through his alma mater. Alejandro's dissertation explores how corrupt politicians in Mexico avoid accountability at the ballot box by buying off voters as well as exposing corruption in the auditing process of public finances at the state and local level. Through the use of econometric methods, he demonstrates that mayors are systematically embezzling money during election years and through the use of network models he finds that auditors avoid investigating corrupt mayors. As a first-generation

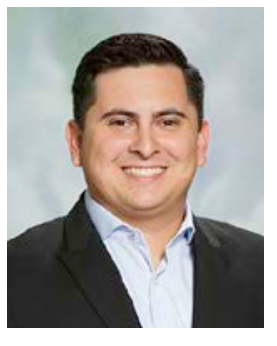
college graduate and first-generation immigrant, Alejandro understands the barriers that many Latino students face when choosing to enter grad school, which motivates his goal of recruiting more Latino undergrads into $\mathrm{PhD}$ programs. Alejandro is excited to use the support of the Fund for Latino Scholarship to travel to the 2019APSA Annual Meeting to present his research and to interview for potential tenure track positions at minority serving institutions where he can fulfill his goal of mentoring students and recruiting them into political science and graduate school.

Tabitha Bonilla is currently a research assistant professor at Northwestern University's Institute for Policy Research. Tabitha earned her PhD from Stanford University, and previously worked as a Post-Doctoral Scholar and Teaching Fellow at the University of Southern California. Her research and teaching interests are at the intersection of political communication, representation, and identity. Her work includes understanding how communication matters for represen-

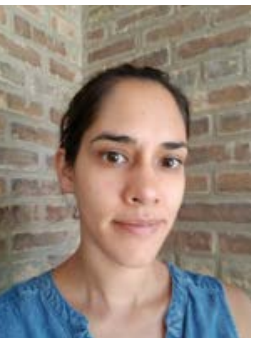
tation as well as how various communications alter support for public policies and social movements, including immigration, human trafficking, and Black Lives Matter. In one current project, Tabitha investigates how descriptive and substantive representation inform each other. The award from the Fund for Latino Scholarship will pay for gift card rewards for interview participants in summer 2019.

Álvaro José Corral received his Ph.D. in Government from the University of Texas at
Austin. His research is in the areas of Latinx Politics and Race and Ethnicity in American Politics, with a focus on the public opinion and voting behavior of Latinxs as well as immigration policy. Between 2017 and 2019 Álvaro was a Consortium for Faculty Diversity Postdoctoral Fellow, and beginning in the fall of 2019 he will join the Department of Political Science at The College of Wooster at the rank of assistant professor. His book project, an extension of his dissertation, explores the relationship between gener-

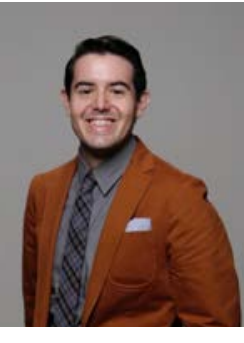
ational status and civic institutions as a new way to understand the political integration process of Latinx immigrants and their US-born family members. He is also a co-principal investigator for the Immigrant Worker Survey Project, a collaborative project across four liberal arts colleges that collected over 300 in-depth interviews with Latinx migrants in Ohio in partnership with a community-based organization. He plans to use funds from the Latino Scholarship award to conduct focus group interviews with Latinx participants for his book project.

Angela Gutierrez is a $2019-2020$ Marvin Hoffenberg fellow and a senior policy fellow at the Latino Politics and Policy Initiative (LPPI) at the University of California, Los Angeles. Her research focuses on the role of political threat on Latino identity and political participation. Her co-authored paper "Somos Más: How Racial Threat and Anger Mobilized Latino Voters in

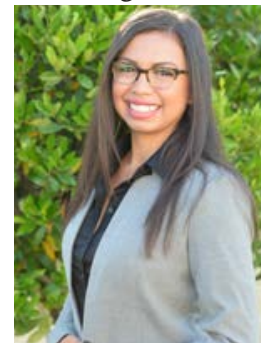
The Trump Era" was recently published in $P R Q$. Her dissertation explores how identity can be activated and subsequently influence political behavior. She will use the financial support provided by the Fund for Latino Scholarship help fund an experiment for her dissertation that aims to disentangle how different identity measures such as linked fate and group consciousness influence political attitudes and behaviors of Latinos in the United States. 
Michelangelo Landgrave is a doctoral student at the University of California, Riverside. His research focuses on representation and legislative studies. In addition to his academic research, he regularly publishes policy briefs on immigration policy. His research has been cited by such media as the Washington Post and The Hill. He will use his award from the Fund for Latino

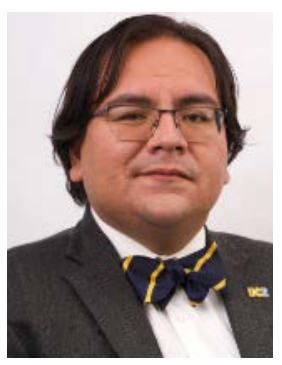
Scholarship to fund research related to his dissertation. His dissertation develops a new theory of legislative discrimination using experiments with political elites.

Eddie Lucero is a third-year graduate student at the University of California, Merced's PhD program in Political Science. His interests lie in Latino politics broadly, investigating both institutional and behavioral factors that influence Latino participation in American politics and the formation of a Latino Group Conscious. He completed

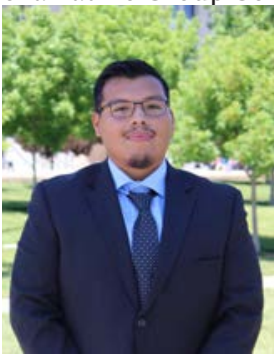
his BA in political science at UC Merced in the Fall of 2016 and worked for a California state legislator during and after his undergraduate studies. Eddie is a recipient of the Eugene Cota Robles Fellowship and has recently presented work at the 2019 Western Political Science Conference. The award from the Fund for Latino scholarship will aid in the completion of his current study on how bilingualism among Latinos effects their perceptions of American politics and opinion formation. His goal is to present this work at the next Western Political Science Conference in 2020. This work will further the Latino Scholarship's mission by investigating how bilingualism (English and Spanish), among a growing bilingual Latino electorate, effects Latino participation and perception of American politics.

Eduardo Salinas is currently a doctoral candidate studying political science at The University of Illinois at Chicago. His research links issues of race, racism, Latino assimilation/immigration, public opinion, survey methodology, and policy preferences. His peer-reviewed published work can be found in Community Development, The Journal of Politics in Latin America, and The Routledge Companion to Race and Ethnicity (2nd ed., forthcoming 2020). Eduardo is also currently a Research Methodologist at The National Opinion Research Center (NORC) at the University of Chicago. While at NORC, he has worked most extensively on the General Social Survey (GSS) in a variety of roles. The 2019 APSA Fund for Latino Scholarship will contribute to Eduardo's ongoing

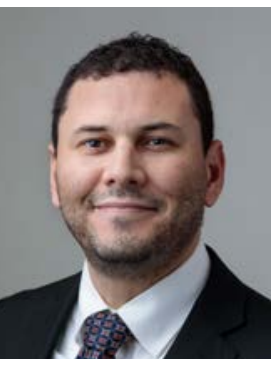
research into minority-on-minority racism, and its effects on Latino public policy preferences. Eduardo received his BA in International Studies from The University of North Texas before attending the University of Illinois at Chicago.

Inés Valdez is an associate professor of political science at the Ohio State University and the director of the Latina/o Studies Program. Her work focuses on the political theory of race, migration, empire, and cosmopolitanism. Her first book, Transnational Cosmopolitanism: Kant, Du Bois, and Justice as a Political Craft, was published in June of 2019 with Cambridge Univer-

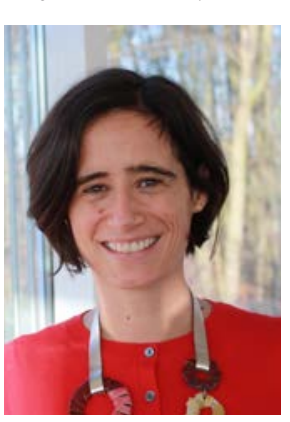
sity Press. The book theorizes the notion of transnational cosmopolitanism to move the debate away from neo-Kantian accounts of cosmopolitanism toward a grounded, relational, and dialectical approach of transnational justice based on neglected portions of W. E. B. Du Bois's work. Her work has appeared in the American Political Science Review, Political Research Quarterly, and Political Studies among other outlets. She has held or currently holds fellowships from the European University Institute, the Princeton University Center for Human Values, and the Humboldt Stiftung. She is currently at work on a book manuscript on imperial mobility and the origins of popular sovereignty. The APSA Fund for Latina/o Scholarship will support-alongside an institutional match-a summer research stipend for an Ohio State graduate student who is Latina/o/x or whose research is on Latina/o/x politics.

Daisy Vazquez Vera is a doctoral student in the political science department at UCLA focusing on immigrant political representation and participation. She graduated from UC Irvine in 2017 with a BA in political science and Chicano/Latino studies. Her current work studies how immigrant-serving organizations mediate the representation process for undocumented immigrant constituents across states and localities. Daisy's previous research has examined the impact of institutional practices that support educational equity for undocumented immigrant college students and the legislative process and implementation of state-level immigrant policies. She is currently a senior research fellow at the UCLA Latino Policy and Politics Initiative conducting research on the topics of Latino representa-

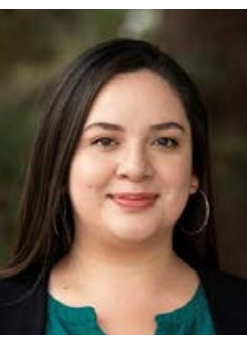
tion and voting rights. Daisy is a recipient of the Ford Predoctoral Fellowship, 2018 APSA Minority Fellowship and the Eugene V.Cota-Robles fellowship from UCLA. The Fund for Latino Scholarship will allow her to continue data collection efforts for her project on the role of immigrant-serving organizations' advocacy efforts on legislative behavior and policy outcomes. 


\section{Introducing the 2019-2020 APSA Congressional Fellows}

\section{Thanks to the 2019 - 2020 Selection Panel}

Michelle Chin (CFP 2006-2007), Jessica Gerrity (CFP 2006-2007), John Haskell (CFP 1997-1998), Tyson King-Meadows (CFP 2012-2013), and Marvin Overby (CFP 1988-1989)

\section{POLITICAL SCIENCE FELLOWS}

Carlos Algara, PhD - University of California, Davis

Christian Fong, PhD - Assistant Professor, University of Michigan

Paul Musgrave, PhD - Assistant Professor, University of Massachusetts, Amherst

Ryan Vander Wielen, PhD - Associate Professor, Temple University

Catherine Wineinger, PhD - Assistant Professor, Western Washington University

MCI/COMMUNICATIONS FELLOWS

Joel Reed, PhD candidate, University of Missouri

JOURNALISM FELLOW

Sofia Resnick, Rewire.News, Washington, DC
Congressional

Fellowship Program

Advisory Committee

\author{
Michelle Chin* \\ Joan Claybrook* \\ Richard Cohen \\ Charles E. Cook, Jr. \\ Menna Demessie* \\ Robert Dole \\ Ronald D. Elving* \\ Vic Fazio \\ Michael Franc \\ David Gergen \\ Lee H. Hamilton \\ Gerald Kovach \\ Paul Light* \\ Richard Lugar \\ Rep. David Price \\ Cokie Roberts \\ Catherine E. Rudder* \\ James Thurber*
}

*Former APSA Congressional Fellow

\section{Apply this Fall for the 2020-2021 Fellowship Year}

\section{FELLOWSHIP YEAR}

Fellows begin their fellowship year with a comprehensive four-week orientation with congressional experts and policy leaders. Orientation begins in November 2020. Fellows then serve full-time assignments as legislative aides in the House of Representatives or Senate. Office placements run until August 15, 2021. Candidates may apply for two optional programs-a research fellowship and a course on Congress and foreign policy-that run from September to October 2020. The fellowship year also features a winter and spring seminar series on Congress, a visit to the district or state of a Member of Congress, and optional programs in Annapolis, Maryland, and Ottawa, Canada.

\section{QUALIFICATIONS}

Applications are welcome from political scientists who have completed a $\mathrm{PhD}$ in the last 15 years or will have defended a dissertation in political science by November of the fellowship year. The program is open to scholars in all subfields within political science who can show a scholarly interest in Congress and policy making.

\section{STIPEND}

$\$ 52,500$ for the 9.5-month fellowship period, plus a travel allowance.

\section{HOW TO APPLY}

The application period opens in September 2019. Applications must be submitted online and include:

- A 500-word personal statement

- The names and contact information for three references

- A writing sample.

Learn more at http://www.apsanet.org/cfp. 


\section{Achieving Diversity and Inclusion in Political Science}

\section{Diversity and Inclusion Programs}

The American Political Science Association has several major programs aimed at enhancing diversity within the discipline and identifying and aiding students and faculty from underrepresented backgrounds in the political science field. These programs include:

Ralph Bunche Summer Institute (RBSI) (Undergraduate Juniors)

The RBSI Program is an annual five-week program designed to introduce to the world of doctoral study in political science to those undergraduate students from under-represented racial/ethnic groups or those interested in broadening participation in political science and pursuing scholarship on issues affecting underrepresented groups or issues of tribal sovereignty and governance. Application deadline: January of each year. For more information, visit www.apsanet.org/rbsi.

APSA Minority Fellows Program (MFP) (Undergraduate Seniors or MA and PhD students) (Fall Cycle for seniors and MA Students, Spring Cycle for PhD students) MFP is a fellowship competition for those applying to graduate school, designed to increase the number of individuals from under-represented backgrounds with PhD's in political science. Application deadline: October and March of each year. For more information, visit www.apsanet.org/mfp.

Minority Student Recruitment Program (MSRP) (Undergraduates and Departmental members) The MSRP was created to identify undergraduate students from under-represented backgrounds who are interested in, or show potential for, graduate study and, ultimately, to help further diversify the political science profession. For more information, visit www.apsanet.org/msrp.

\section{APSA Mentoring Program}

The Mentoring Program connects undergraduate, graduate students, and junior faculty to experienced and senior members of the profession for professional development mentoring. APSA membership is required for mentors. To request a mentor or be a mentor, visit www.apsanet.org/mentor.

\section{APSA Status Committees}

APSA Status Committees develop and promote agendas and activities concerning the professional development and current status of under-represented communities within the political science discipline. For a listing of all APSA status committees, visit www.apsanet.org/status-committees.

For more information on all Diversity and Inclusion Programs, visit us online at www.apsanet.org/ diversityprograms. Please contact Kimberly Mealy, PhD, Senior Director of Diversity and Inclusion Programs with any questions: kmealy@apsanet.org.

To contribute to an APSA Fund, such as the Ralph Bunche Endowment Fund or the Hanes Walton Jr. Fund, visit us at www.apsanet.org/donate. 